\title{
18F-FDG PET/CT Findings of a Patient with Wegener's Granulomatosis Before and After Therapy
}

\author{
Wegener Granülomatoz Tanılı Bir Olgunun Tedavi Öncesi ve Sonrası \\ I8F-FDG PET/BT Bulguları
}

\author{
Elif Özdemir', Nilüfer Yıldırım Poyraz' ${ }^{1}$ Ayşegül Şentürk², Ebru Uz³, Mutlay Keskin'1, Levent Yüksel³, Zuhal Kandemir1, \\ Şeyda Türkölmez' \\ IAtatürk Training and Research Hospital, Clinic of Nuclear Medicine, Ankara, Turkey \\ 2Atatürk Training and Research Hospital, Clinic of Pulmonary Diseases, Ankara, Turkey \\ ${ }^{3}$ Atatürk Training and Research Hospital, Clinic of Nephrology, Ankara, Turkey
}

\begin{abstract}
Wegener's granulomatosis (WG) is a rare form of systemic vasculitis that primarily involves the small-to-medium sized vessels and affects both the kidneys and the upper and lower respiratory tract. In this case report, FDG PET/CT findings of bilateral hypermetabolic lung lesions that mimic malignancy in a patient with WG are presented. The hypermetabolic lesions completely disappeared on follow-up PET/CT scan after treatment with cyclophosphamide. The increased FDG uptake of these lesions substantially regressed following treatment.
\end{abstract}

Key Words: Wegener's granulomatosis, 18F- FDG, positron emission tomography, vasculitis

Conflicts of Interest: The authors reported no conflict of interest related to this article.

\section{Özet}

Wegener granülomatozu (WG) nadir görülen bir sistemik vaskülit olup; orta-büyük damarları tutar ve üst-alt solunum sistemini ve böbrekleri etkiler. Bu olgu sunumunda maligniteyi taklit eden bilateral hipermetabolik akciğer kitleleri izlenen bir WG olgusunun FDG PET/BT görüntüleme bulguları sunulmuştur. WG lezyonlarında izlenen artmış FDG tutulumlarının tedavi sonrası kaybolduğu izlenmiştir.

Anahtar Kelimeler: Wegener granülomatozu, 18F- FDG, pozitron emisyon tomografisi, vaskülit

Çıkar Çatışması: Yazarlar bu makale ile ilgili olarak herhangi bir çıkar çatışması bildirmemiştir.

\section{Introduction}

Wegener's granulomatosis (WG) is a form of systemic vasculitis that affects the respiratory tract and the kidneys. It was originally described by Friedrich Wegener as rhinogenic granulomatous disease in 1936 (1). When untreated, the clinical progression is rapid, with severe inflammation and renal failure. Early diagnosis is thus crucial for improving prognosis $(2,3)$. WG is an ANCA-related vasculitis that is associated with increased 18F-Fluorodeoxyglucose (FDG) uptake on positron emission tomography/computed tomography (PET/CT). This case report describes the FDG $\mathrm{PET} / \mathrm{CT}$ findings of a patient with WG, before and after immune-suppression therapy. 


\section{Case Report}

A 26-year-old male patient was admitted to the hospital with complaints of dry cough, weight loss, asthenia and back pain for 2 months. His chest X-ray was normal. The thoracic computed tomography (CT) imaging revealed apical soft tissue masses in both lungs, a parenchymal nodule in the right lung and anterior mediastinal, paratracheal and bilateral hilar lymph nodes. His creatinine level was 5.8 $\mathrm{mg} / \mathrm{dL}$, while the remaining biochemical tests were within normal limits.

Immunological tests were normal except for Antineutrophil cytoplasmic antibodies, with a positive cytoplasm pattern (C-ANCA) test. Endobronchial ultrasonography guided biopsy of the paratracheal lymph node that was evident on $\mathrm{CT}$, revealed intense lymphocyte infiltration without atypical cells. The patient was readmitted within a couple of days due to fever, malaise and ankle swelling. A tru-cut transthoracic biopsy (TTB) was inconclusive and the patient underwent FDG PET/CT imaging with the presumptive diagnosis of lung cancer.

There was evidence of increased FDG uptake at the $50 \times 45 \times 33 \mathrm{~mm}$ in size, centrally hypometabolic, irregular mass that was located at the apex of the right lung (SUVmax: 10.2), and at the $41 \times 24 \times 21 \mathrm{~mm}$ lesion with similar characteristics located at the apicoposterior segment of the left upper lung lobe (SUVmax: 10.1).

In addition, a parenchymal lesion at the apicoposterior segment of right upper lung lobe that measured $16 \mathrm{~mm}$ in size showed increased FDG uptake (SUVmax: 4.06). There were hypermetabolic lymph nodes (SUVmax: 5.7) at the anterior mediastinal, right paratracheal, prevertebral and bilateral hilar sites, the largest being $12 \mathrm{~mm}$ in size (Figure 1). The findings were regarded as likely to be malignant. A repeat TTB of the right lung lesion was compatible with necrotizing granulomatous vasculitis. Together with the positive test for C-ANCA, this finding led to the diagnosis of WG without upper respiratory tract involvement. Our patient was successfully treated with plasmapheresis, steroids, and cyclophosphamide (CPA) therapy. He was discharged with a schedule of ongoing treatment. Upon 6 cycles of cyclophosphamide therapy, a follow-up PET/ CT imaging was undertaken, which revealed that both the hypermetabolic lung lesions and hypermetabolic lymph nodes completely resolved, consistent with response to therapy (Figure 2).

\section{Literature Review and Discussion}

WG is a rarely encountered form of vasculitis that involves the respiratory tract and the kidneys. It may be associated with increased FDG uptake similar to large vessel vasculitic syndromes such as Takayasu arteritis and giant cell arteritis $(4,5,6)$. Oral CPA and glucocorticoids are recommended as first-line therapy in WG and lead to complete resolution in nearly $75 \%$ of cases (7).
FDG PET/CT imaging is widely utilized for the differential diagnosis of benign and malignant pulmonary nodules (8). Despite a high level of clinical precision, infectious and inflammatory processes may lead to false positive findings on FDG PET/CT. WG should be kept in mind in the differential diagnosis of hypermetabolic lung lesions. Neither PET nor CT findings are specific for WG $(9,10)$.

There are several case reports and series regarding the use of FDG PET/CT in WG $(5,11,12,13,14,15,16)$. In a report of 8 patients by Ito et al., WG lesions of the upper respiratory tract and lung were more clearly detected by
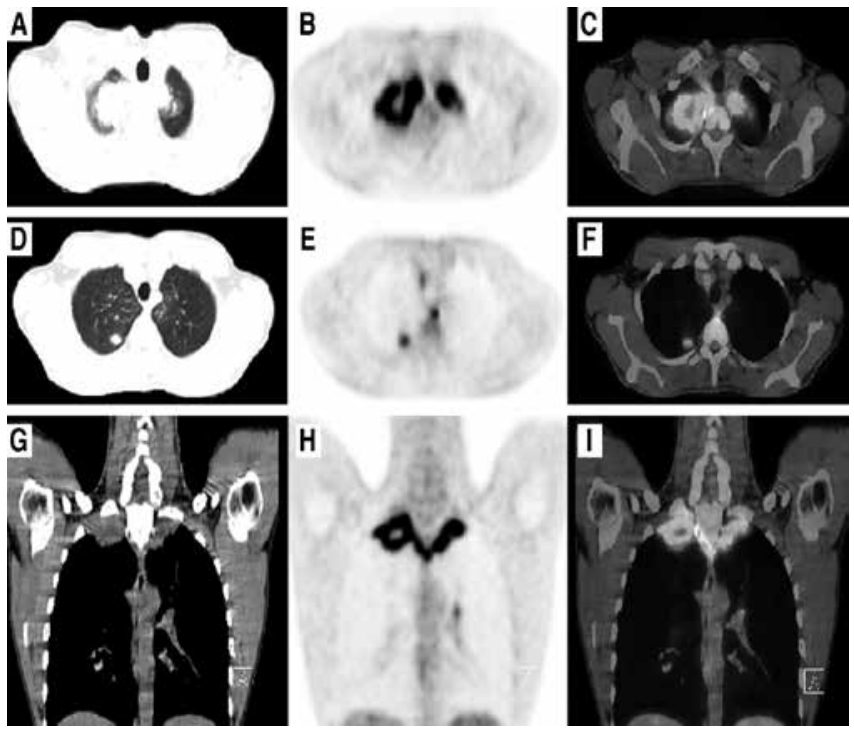

Figure 1. Axial $C T$ (in lung window; $A, D), P E T(B, E)$, and fused PET/CT images (C, F) and coronal CT (in mediastinal window; $G$ ), PET $(H)$ and fused PET/CT (I) images revealed increased 18F-FDG uptake at bilateral apical masses and a distinct parenchymal lesion at apicoposterior segment of the right lung

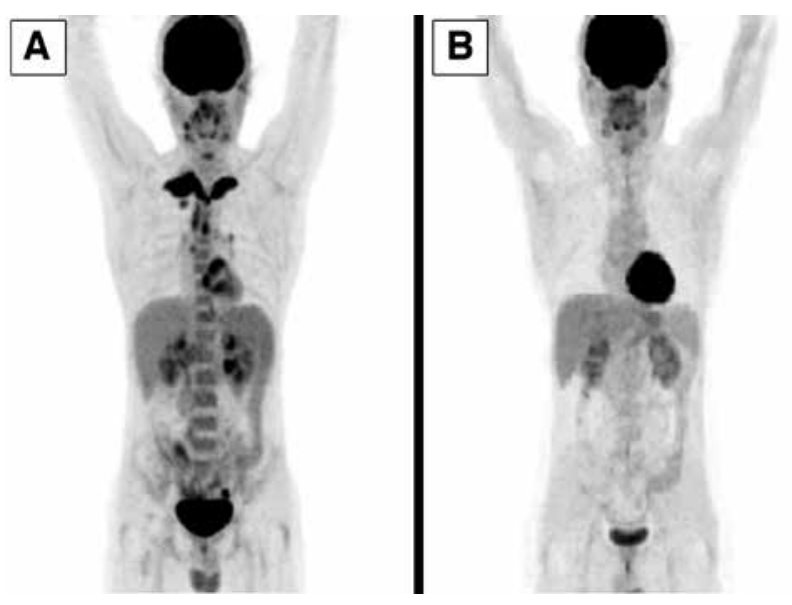

Figure 2. MIP FDG PET/CT images before $(A)$ and seven months after treatment (B) showed markedly increased FDG uptake mimicking malignancy in pulmonary lesions at the upper lobes of both lungs, mediastinal and bilateral hilar lymph nodes before treatment $(A)$ and no uptake at these sites on follow-up PET/CT after treatment (B) 
FDG PET/CT fusion imaging than by un-enhanced CT alone, and all of the active lesions showed decreased FDG uptake after treatment (5). Ueda et al. proposed that WG may be diagnosed earlier if FDG PET/CT is applied more widely to evaluate patients with unexplained systemic inflammatory diseases. In addition, this technique is beneficial for evaluating recurrence and spatial expansion of WG (11). Ozmen et al. evaluated pulmonary and non-pulmonary involvement in a series of 13 WG patients by FDG PET/CT, and found evidence of involvement in the spleen and the adrenal glands in addition to the upper respiratory tract and the lungs (12). They evaluated the response to therapy by FDG PET/CT in only 2 out of 13 cases, and reported either complete resolution or decreased uptake on followup scans. Aydın et al. reported a case with intense FDG uptake in the upper and lower respiratory system. The diagnosis of WG was based on PET findings, elevated serum levels of inflammatory markers, and the presence of c-ANCA (14). Almuhaideb et al. reported an interesting case of WG with unusual multiorgan involvement (15). FDG PET/CT showed involvement of the maxillary sinus, nasal cavity and parotid gland with local extension to middle ear cleft, mediastinum, lungs and prostate. Umemoto et al. described a case of relapsed WG that presented with abdominal pain, peri-iliac arterial soft tissue inflammation resulting in urethral obstruction and hydronephrosis (16). They concluded that FDG-PET/CT was a useful tool to diagnose WG relapses.

In our case with WG, lung lesions and hypermetabolic lymph nodes on FDG PET/CT, that could otherwise be misdiagnosed as malignancy, were shown to completely disappear after successful treatment of WG by CPA and glucocorticoids. Although it may not be truly diagnostic, FDG PET/CT may be useful to determine the extent of disease and response to therapy in WG.

\section{References}

1. Woywodt A, Matteson EL. Wegener's granulomatosi-probing the untold past of the man behind the eponym. Rheumatology (Oxford) 2006;45:1303-1306.

2. Hoffman GS, Kerr GS, Leavitt RY, Hallahan CW, Lebovics RS, Travis WD, Rottem M, Fauci AS. Wegener granulomatosis: an analysis of 158 patients. Ann Intern Med 1992:116:488-498.
3. Slot MC, Tervaert JW, Franssen CF, Stegeman CA. Renal survival and prognostic factors in patients with PR3-ANCA associated vasculitis with renal involvement. Kidney Int 2003;63:670-677.

4. Belhocine T, Blockmans D, Hustinx R, Vandevivere J, Mortelmans L. Imaging of large vessel vasculitis with (18)FDG PET: illusion or reality? A critical review of the literature data. Eur J Nucl Med Mol Imaging 2003:30:1305-1313.

5. Ito K, Minamimoto R, Yamashita H, Yoshida S, Morooka M, Okasaki $M$, Mimori A, Kubota K. Evaluation of Wegener's granulomatosis using 18F-fluorodeoxyglucose positron emission tomography/ computed tomography.Ann Nucl Med 2013;27:209-216.

6. Sağer S, Yılmaz S, Ozhan M, Halaç M, Ergül N, Ciftci H, Cermik TF. F-18 FDG PET/CT Findings of a Patient with Takayasu Arteritis Before and After Therapy. Mol Imaging Radionucl Ther 2012;21:32-34.

7. Hoffman GS, Kerr GS, Leavitt RY, Hallahan CW, Lebovics RS, Travis WD, Rottem M, Fauci AS. Wegener granulomatosis: an analysis of 158 patients. Ann Intern Med 1992;116:488-498.

8. Bar-Shalom R, Kagna O, Israel O, Guralnik L. Noninvasive diagnosis of solitary pulmonary lesions in cancer patients based on 2-fluoro-2deoxy-D-glucose avidity on positron emission tomography/computed tomography. Cancer 2008;113:3213-3221.

9. Ananthakrishnan L, Sharma N, Kanne JP. Wegener's granulomatosis in the chest: high-resolution CT findings. AJR Am J Roentgenol 2009;192:676-682

10. Martinez F, Chung JH, Digumarthy SR, Kanne JP, Abbott GF, Shepard JA, Mark EJ, Sharma A. Common and uncommon manifestations of Wegener granulomatosis at chest CT: radiologic-pathologic correlation. Radiographics 2012;32:51-69.

11. Ueda $N$, Inoue $Y$, Himeji $D$, Shimao $Y$, Oryoji $K$, Mitoma $H$, Arinobu $Y$, Niiro $H$, Tsukamoto $H$, Horiuchi T, Ueda A, Akashi K. Wegener's granulomatosis detected initially by integrated 18F-fluorodeoxyglucose positron emission tomography/computed tomography. Mod Rheumatol 2010;20:205-209.

12. Ozmen O, Tatci E, Gokcek A, Koksal D, Dadali Y, Ozaydin E, Arslan N Integration of 2-deoxy-2-(18F) fluoro-D-glucose PET/CT into clinical management of patients with Wegener's granulomatosis. Ann Nucl Med 2013;27:907-915

13. Beggs AD, Hain SF. F-18 FDG-positron emission tomographic scanning and Wegener's granulomatosis. Clin Nucl Med 2002;27:705-706

14. Aydin M, Akkoyunlu ME, Yakar F, Ergul N, Sezer M. Intense FDG uptake on PET/CT in the upper and lower respiratory system indicative of Wegener's granulomatosis. Rev Esp Med Nucl Imagen Mol 2014;33:32-35

15. Almuhaideb A, Syed R, lordanidou L, Saad Z, Bomanji J. Fluorine-18fluorodeoxyglucose $\mathrm{PET} / \mathrm{CT}$ rare finding of a unique multiorgan involvement of Wegener's granulomatosis. Br J Radiol 2011;84:202204.

16. Umemoto A, Ikeuchi H, Hiromura K, Hamatani H, Sakurai N, Sakairi T, Matsumoto T, Maeshima A, Kuroiwa T, Nojima Y. Hydronephrosis caused by a relapse of granulomatosis with polyangiitis (Wegener's). Mod Rheumatol 2012:22:616-620. 